\title{
Comparison of two- and three-compartment cells for electrodialytic removal of heavy metals from contaminated material suspensions
}

Kirkelund, Gunvor Marie; Jensen, Pernille Erland; Ottosen, Lisbeth M.; Pedersen, Kristine B.

Published in:

Journal of Hazardous Materials

Link to article, DOI:

10.1016/j.jhazmat.2018.12.063

Publication date:

2019

Document Version

Peer reviewed version

Link back to DTU Orbit

Citation $(A P A)$ :

Kirkelund, G. M., Jensen, P. E., Ottosen, L. M., \& Pedersen, K. B. (2019). Comparison of two- and threecompartment cells for electrodialytic removal of heavy metals from contaminated material suspensions. Journal of Hazardous Materials, 367, 68-76. https://doi.org/10.1016/j.jhazmat.2018.12.063

\section{General rights}

Copyright and moral rights for the publications made accessible in the public portal are retained by the authors and/or other copyright owners and it is a condition of accessing publications that users recognise and abide by the legal requirements associated with these rights.

- Users may download and print one copy of any publication from the public portal for the purpose of private study or research.

- You may not further distribute the material or use it for any profit-making activity or commercial gain

- You may freely distribute the URL identifying the publication in the public portal 


\section{Accepted Manuscript}

Title: Comparison of two- and three-compartment cells for electrodialytic removal of heavy metals from contaminated material suspensions

Authors: Gunvor M. Kirkelund, Pernille E. Jensen, Lisbeth M. Ottosen, Kristine B. Pedersen

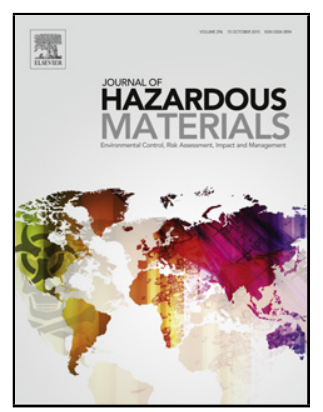

PII: S0304-3894(18)31212-3

DOI:

Reference: https://doi.org/10.1016/j.jhazmat.2018.12.063

To appear in: HAZMAT 20097

Received date: Journal of Hazardous Materials

Revised date:

26 September 2017

Accepted date:

14 December 2018

17 December 2018

Please cite this article as: Kirkelund GM, Jensen PE, Ottosen LM, Pedersen KB, Comparison of two- and three-compartment cells for electrodialytic removal of heavy metals from contaminated material suspensions, Journal of Hazardous Materials (2018), https://doi.org/10.1016/j.jhazmat.2018.12.063

This is a PDF file of an unedited manuscript that has been accepted for publication. As a service to our customers we are providing this early version of the manuscript. The manuscript will undergo copyediting, typesetting, and review of the resulting proof before it is published in its final form. Please note that during the production process errors may be discovered which could affect the content, and all legal disclaimers that apply to the journal pertain. 


\title{
Comparison of two- and three-compartment cells for electrodialytic removal of heavy metals from contaminated material suspensions
}

\author{
Gunvor M. Kirkelund ${ }^{1}$ Pernille E. Jensen ${ }^{1}$, Lisbeth M. Ottosen ${ }^{1}$, Kristine B. Pedersen ${ }^{2}$ \\ ${ }^{1}$ Department of Civil Engineering, Technical University of Denmark, \\ ${ }^{2}$ Akvaplan-niva, Norway
}

${ }^{1}$ CORRESPONDING AUTHOR: GUNVOR M. KIRKELUND, DTU CIVIL ENGINEERING, BROVEJ, BUILD. 118, DK-2800 KGS. LYNGBY, DENMARK, GUNKI@BYG.DTU.DK

\section{Highlights:}

- A two-compartment electrodialytic cell was compared to a three-compartment cell

- Multivariate analysis was used to evaluate key characteristics of metal removal

- Acidification of the material suspension is faster in the two-compartment cell

- An important current carrier is $\mathrm{Ca}^{2+}$ in all materials

- Cell choice depends on material characteristics for optimal heavy metal removal

\begin{abstract}
Electrodialytic remediation can be applied to remove heavy metals from contaminated particulate materials in suspension. The applied electric current is the cleaning agent and the heavy metals are removed by electromigration. In this study, a two-compartment cell was compared to a threecompartment cell, for several contaminated materials such as soils, sediments, mine tailings and ashes and totally 20 experiments were conducted. The $\mathrm{pH}$ decrease was faster in the twocompartment cell, but the metal removal was higher in the three-compartment cell since anionic metal species are removed from the material suspension in this cell set-up. For materials with relatively high chloride content, fly ash and harbour sediments, up to $38 \%$ of the metals were found in the filtrate in the two-compartment cell. Up to $9 \%$ of the current was used to transport heavy metal ions in the experiments and the current was mainly carried by $\mathrm{H}^{+}$and $\mathrm{Ca}^{2+}$. Even with the lower $\mathrm{pH}$ in the two-compartment cell experiments, there was little difference in the percentage of the current carried by the metal ions between the two set-ups. Multivariate analysis showed that the choice of cell set-up depends on the metals targeted by remediation and the material characteristics.
\end{abstract}


Keywords: Electrokinetic remediation, electrochemical treatment, waste material, multivariate analysis

\section{Introduction}

Electrodialytic remediation is a known technique for extracting heavy metals from contaminated materials such as wood chips, soil, sediment, fly ashes and mine tailings (e.g. [1-4]). Initially, electrodialytic remediation was developed for soil remediation in a stationary set-up with a water or enhancement solution, for instance, ammonium citrate [5] saturated soil that was placed in the desalination compartment of the cell. With the success of electrodialytic soil remediation, other porous contaminated materials were also subjected to electrodialytic remediation. In some cases, this stationary cell set-up gave severe operational problems, especially when materials had high solubility (e.g. fly ashes) and the remediation also progressed slowly through the material with remediation times up to several months for remediation of soil in a $15 \mathrm{~cm}$ long column for materials with high buffer capacity. Thus, a stirred three-compartment electrodialytic cell was introduced in the early 2000s [3,6] as an alternative to the stationary cell-set up. As a continuation of the development of electrodialytic remediation, a new two-compartment electrodialytic cell has been developed and patented at the Technical University of Denmark [7], seen in Fig. 1 together with the traditional three-compartment cell.

The main difference between the two-compartment and the three-compartment cell is the direct acidification by the anode $\left(\mathrm{H}_{2} \mathrm{O} \rightarrow 2 \mathrm{H}^{+}+1 / 2 \mathrm{O}_{2}(\mathrm{~g})+2 \mathrm{e}^{-}\right)$in the material suspension in the twocompartment cell $[7,8]$. In the three-compartment cell, the acidification of the material suspension is caused mainly by water-splitting at the anion exchange membrane [9]. Acidification is necessary to release the metals from the material into the liquid phase. At acidic $\mathrm{pH}$, the main speciation will be as charged metal ions that can electromigrate in the electric field. The two-compartment cell set-up has proven successful for electrodialytically treatment of sewage sludge ashes, with transport of heavy metals to the catholyte and extraction of phosphorus in the anolyte (compartment I in the two-compartment cell in Fig. 1) compared to the traditional three-compartment cell [8], since phosphorus species may be uncharged as well as negatively charged. From the liquid of compartment I in the two-compartment cell (Fig. 1) a very pure phosphorous salt can be obtained by filtration and evaporation [10]. The twocompartment cell set-up was tested for metal removal from other materials such as sediments and fly ash [11,12]. Pedersen et al., [11] found that the experimental current density and duration was more important for the metal removal from sediments, rather than the cell set-up. Kirkelund et al. [12] found that the final $\mathrm{pH}$ in the fly ash/air pollution control residue suspension was crucial for the optimal heavy metal removal and that the two-compartment cell did not positively affect the metal removal. However, a significant advantage of the two-compartment cell is the simpler set-up, which implies lower costs for pilot scale trials and industrial use. Therefore, it is interesting to investigate the efficiency of the two-compartment set-up for other materials and to elucidate which of the two set-ups is most efficient for removing heavy metals from different contaminated particulate materials. Multivariate models of either harbour sediments or soil have previously been used to design remediation of new similar materials by their characteristics [1315]. These studies have revealed that there is a need to focus on material characteristics during electrodialytic remediation to increase the statistical database of different materials in order to enable prediction of remediation of materials based on their characteristics. 
The aims of this study were to investigate 1) the removal efficiency of $\mathrm{As}, \mathrm{Cd}, \mathrm{Cr}, \mathrm{Cu}, \mathrm{Pb}$ and $\mathrm{Zn}$ in the two different cell set-ups from several contaminated materials 2) to determine the main current carrier (previously unexamined in the stirred set-up) and 3) identify the most important parameters for the metal removal by application of statistical multivariate analysis.

\section{Experimental}

\subsection{Experimental materials}

In total ten different samples ( 2 soils, 3 sediments, 3 ashes and 2 mine tailings) were used in the experiments, see Table 1. For the sewage sludge ash from Avedøre (SSA1) a different batch than the batch used in Ebbers et al., [8] was used in the experimental work. The two experimental harbour sediments were from other sampling locations than used by Pedersen et al. [11]. The new sewage sludge batch and harbour sediment samples were included in the study to get representative data for the experimental materials as the previous experiments did not include analysis of the major elements and/or had different experimental settings for the electrodialytic experiments.

\subsection{Electrodialytic experiments}

Two electrodialytic experiments were run for each material, both in the two- and the threecompartment cell (Fig. 1), summing up to 20 experiments. All experiments had a duration of 7 days at a constant current. The current density was $0.2 \mathrm{~mA} / \mathrm{cm}^{2}$ for materials with low electrical conductivity (soil, mine tailing and lake sediment) and $1.0 \mathrm{~mA} / \mathrm{cm}^{2}$ for materials with high electrical conductivity (fly ash, sewage sludge ash and harbour sediment) to avoid water-splitting at the cation-exchange membrane. The current densities were calculated for the full membrane area, based on applied currents of $10 \mathrm{~mA}$ and $50 \mathrm{~mA}$ for the materials with low and high electrical conductivity, respectively.

The experimental cells were made of Plexiglas and the suspension compartment was $10 \mathrm{~cm}$ long, with an inner diameter of $8 \mathrm{~cm}$. The suspensions were stirred by an IKA RW11 Basis Lab Egg motor (app. $1500 \mathrm{rpm}$ ). The suspensions were made by mixing $100 \mathrm{~g}$ of dry material with 350 $\mathrm{mL}$ of distilled water, i.e. liquid to solid ratio of 3.5. The dry material was first added to the suspension cell compartments; II in the three-compartment cell and I in the two-compartment cell (Fig. 1). Then the $350 \mathrm{~mL}$ of distilled water was gradually added through the stirrer opening of this compartment. The stirrer was made of a flexible plastic flap fastened to a glass rod. The stirrer was attached and the stirring started shortly, after the first suspension sample for measuring $\mathrm{pH}$ and $\mathrm{EC}$ was taken. During the electrodialytic experiments, $\mathrm{pH}$ and electrical conductivity (EC) were measured daily by Radiometer electrodes in the suspensions. In the catholyte and the anolyte (only for the three-compartment experiments) $500 \mathrm{~mL}$ of $0.01 \mathrm{M}$ $\mathrm{NaNO}_{3}, \mathrm{pH}<2$ adjusted with $\mathrm{HNO}_{3}$ were circulated. $\mathrm{pH}$ in the catholyte was adjusted daily during the experiments to $\mathrm{pH} 2$ with $7 \mathrm{M} \mathrm{HNO}_{3}$. The electrodes were made of platinum coated titanium wire (diameter $3 \mathrm{~mm}$ ) obtained from Permascand. A Hewlett Packard E3612A power supply was used to maintain a constant electric DC current. The ion exchange membranes were 
obtained from Ionics (anion exchange membrane 20 SZRA B02249C and cation exchange membrane CR67 HUY N12116B).

After the experiments, the suspension was filtered through a $45 \mu \mathrm{m}$ filter and the treated material dried at $40^{\circ} \mathrm{C}$ before further digestion and heavy metal analysis. The membranes and stirrer were placed in $1 \mathrm{M} \mathrm{HNO}_{3}$ and the electrodes in $5 \mathrm{M} \mathrm{HNO}_{3}$. All liquid samples including suspension liquid and electrolytes were kept for heavy metal analysis.

\subsection{Analytical procedures}

The $\mathrm{pH}$ of the materials was measured in $1 \mathrm{M} \mathrm{KCl}$ at a liquid-to-solid ratio (L/S) of 5 and after 1 hour of agitation, $\mathrm{pH}$ was measured by a Radiometer Analytical $\mathrm{pH}$ electrode. Metal content (As, $\mathrm{Cd}, \mathrm{Cr}, \mathrm{Cu}, \mathrm{Pb}$ and $\mathrm{Zn}$ ) and major ions ( $\mathrm{Al}, \mathrm{Ca}, \mathrm{Fe}, \mathrm{K}, \mathrm{Mg}$ ) in the experimental materials were measured by ICP-OES (induced coupled plasma- optical emission spectrometry) after digestion by DS 259 [16]. These digestions were made by mixing $1 \mathrm{~g}$ material and $20 \mathrm{~mL} 7.3 \mathrm{M} \mathrm{HNO}_{3}$ that were heated at $200 \mathrm{kPa}\left(120^{\circ} \mathrm{C}\right)$ for $30 \mathrm{~min}$. The liquid was subsequently separated by vacuum filtration through a $45 \mu \mathrm{m}$ filter and diluted to $100 \mathrm{~mL}$. ICP-OES (Induced coupled plasma - optical emission spectrometry) was used to measure metals and major ions in all liquid samples, including samples collected after the electrodialytic experiments.

\subsection{Statistical multivariate analysis}

The principles of multivariate modelling are explained in detail in Carlson and Carlson [17] and adjusted to the conditions in this study. The Simca P11 software was used for the multivariate modelling by principal component analysis (PCA) and projections onto latent structures (PLS). PCA was used to visualize difference and similarities in the materials used in the electrodialytic remediation experiments. Principal components, mutually orthogonal vectors that represent the independent and uncorrelated variance of the initial experimental materials characteristics (variables) were calculated. Correlated characteristics are described by the same principal component. The systematic variance in the experimental materials characteristics is simplified by using fewer new descriptors than the original number of variables, without the loss of systematic information. Since the material characteristics varied in magnitude, the data were logarithmically transformed and centred and scaled to unit variance in the calculated PCA model. R2X is a measure of the fraction of the variables explained by the model and Q2 is an estimate of the reliability of the model, calculated by cross-validation. Score plots were obtained by projecting the original data onto the calculated orthogonal principal component vectors $(t(1)$ and $t(2))$. Materials with similar variance in their characteristics are plotted closer to one another. The influence of each variable to the principal component is reflected in a loading plot. Variables which have a strong contribution to the variance depicted in the score plot are found far from the origin in the loading plot $(0,0)$ on the $\mathrm{p}(1)$ and $\mathrm{p}(2)$ axis. Positively correlated variables are projected close to each other, while negatively correlated variables are projected opposite to each other concerning the axis centre.

PLS was used to evaluate the influence of variables on the removal efficiencies of metals during electrodialytic remediation. The $\mathrm{X}$ matrix consisted of the experimental materials characteristics (Table 2) and current density, and the Y-matrix consisted of the removal efficiencies (Fig. 5) of the metals. As for the PCA, R2Y is a measure of the fraction of the Y-matrix explained by the 
model and Q2 is an estimate of the reliability of the model calculated by cross-validation. Variable Importance in the Projection (VIP) values present the absolute importance of each parameter in the model concerning its correlation to all the responses (Y) and the projection (X). The VIP values are calculated for each $X$ variable by summing the squares of the PLS loading weights, weighted by the amount of sum of squares explained in each model component. The sum of squares of all VIP's is equal to the number of terms in the model, accordingly the average VIP is equal to 1.VIP plots were used to assess the variable importance in the calculated models. To evaluate if the variables had positive or negative impacts on the model responses, coefficient plots were used.

\section{Results and discussion}

\subsection{Material characteristics}

Table 2 shows the calcium concentration, heavy metal content and the initial $\mathrm{pH}$ in all the experimental materials. There is a great variety in the heavy metal content for the different materials, depending on its origin and use. Also, the $\mathrm{pH}$ range of the materials spans from 5.8 to 12.5 which is also an indication of the materials buffering capacity and how fast the material will be acidified in the electrodialytic experiments. Further, the fly ash and the harbour sediments contained significant concentrations of chloride of up to $23 \%$ (data not shown). Thus varying remediation results are expected for the different materials. A PCA model was calculated to evaluate the similarities of the experimental materials and interdependence of their characteristics. This included the characteristics of the materials (Table 2) as well as the current density used in the electrodialytic experiments. Current density, in this case, represents high/low conductivity in the materials, since the electrodialytic remediation of materials with high conductivity were run at a high current density and the electrodialytic remediation of materials with low conductivity were run at low current density.

The PCA scores plot (Fig. 2a) illustrates a span in the variance of characteristics in the materials. Similar materials do not necessarily have a similar composition of metals, $\mathrm{pH}$ and conductivity, as exemplified by the location of Collstrop S1 and KMC S2 far from each other. The harbour (HS1 and HS2) and lake (LS) sediments are located close to one another indicating the similar composition of metals, $\mathrm{pH}$ and conductivity. This means that the selection of experimental materials represents statistically different materials. The accompanying loadings plot (Fig. 2b) illustrates the material characteristics that have strong contributions to the variance in the scores plot. $\mathrm{Ca}, \mathrm{Pb}, \mathrm{Zn}$ and $\mathrm{pH}$ have the highest influence on the spread of the first component in the scores plot; while $\mathrm{As}, \mathrm{Cr}$ and $\mathrm{Cu}$ have the highest influence on the spread in the second component. $\mathrm{Ca}$ and $\mathrm{pH}$ represent the buffer capacity of the experimental materials and are known to influence the efficiency of electrodialytic remediation. The variance in the PCA loadings plot may hence represent a difference in the efficiency of the electrodialytic treatment for different materials. The clustering of $\mathrm{Ca}, \mathrm{Pb}$ and $\mathrm{Zn}$ in the loading plot may indicate that these metals are partly bound in the same minerals in the material, e.g. in carbonates. The clustering of As and $\mathrm{Cr}$ is probably due to the high concentrations of these metals in the Collstrop soil S1, as the site is a former $\mathrm{CCA}(\mathrm{Cu}, \mathrm{Cr}, \mathrm{As})$ contaminated site. The material composition (metals and $\mathrm{pH}$ ) were generally shown to have a larger impact than current density (electrical conductivity) on the variance in the studied experimental space. 


\subsection{Experimental conditions}

The $\mathrm{pH}$ development in the material suspensions during the electrodialytic experiments is shown in Fig. 3. The results showed that the acidification of the material suspensions occurred about one day earlier in the two-compartment cell for most of the materials and a lower $\mathrm{pH}$ up to a factor 2 was reached in the two-compartment experiments compared to the three-compartment experiment during the 7 days of remediation. Oppositely, the sewage sludge ashes and Nalunaq mine tailing (MT 1) were all fully acidified to $\mathrm{pH} 2$ during the one-week remediation time and had the same final $\mathrm{pH}$ in the suspensions. The same results are expected for the other materials with increased remediation time.

The change in the electrical conductivity in the material suspensions during the experiments is illustrated in Fig. 4. The general trend for the two-compartment cell is an increase in the electrical conductivity over time, due to the $\mathrm{H}^{+}$production directly in the material suspension. For alkaline materials, the electrical conductivity also increases in the three-compartment cell over time, probably due to higher desorption/dissolution of chemcial elements at lower $\mathrm{pH}$. The voltage drop for the experiments was dependent on the cell type and the electrical conductivity of the treated material. Generally, the voltage drop was low $(<5 \mathrm{~V})$ when using the twocompartment cell and $<30 \mathrm{~V}$ when using the three-compartment cell. When using the threecompartment cell, for Hammerfest harbour sediment (HS 1), the voltage drop reached the maximum of the power supply ( $135 \mathrm{~V})$, and the applied current could not be maintained due to the low electrical conductivity. For Lundtofte sewage sludge ash (SSA 2) a similar maximum voltage drop was seen in the two-compartment cell, but this was due to a high $\mathrm{pH}$ in the catholyte, and the voltage decreased when the catholyte was acidified. When the voltage drop was above $10 \mathrm{~V}$ in the three-compartment cell, it was typically caused by a low electrical conductivity in the suspension, below $0.4 \mathrm{mS} / \mathrm{cm}^{2}$.

Some operational challenges were observed. Dissolution of the anode was seen in the experiments with Lundtofte sewage sludge ash (SSA 2), this might be due to fluoride in the material, which can form $\mathrm{HF}$ at the anode that can destroy the anode material. However, the fluorine content in the materials was not measured. The three-compartment cell showed liquid flow over the membranes to and from the suspension compartment, especially when treating Lundtofte sewage sludge ash (SSA 2) (electrical conductivity in suspension initially $22 \mathrm{mS} / \mathrm{cm}^{2}$ ) and the fly ash (electrical conductivity in suspension initially $46 \mathrm{mS} / \mathrm{cm}^{2}$ ). This liquid transfer is most likely due to chemical gradients between the compartments with high versus low electrical conductivity in the suspension and electrolyte, respectively. If the electrical conductivity increases due to the dissolution of the material in the suspension, then this can cause osmotic pressure over the membrane and thus move the liquid.

\subsection{Metal removal}

A lower $\mathrm{pH}$ of a factor up to 2 in the suspensions could be reached in the two-compartment cell within the 7 days of remediation, influencing the release of heavy metals from the materials. The overall removal efficiency in the two-compartment cell was, however, not higher than in the 
three-compartment cell as seen in Fig. 5. The amount of material remaining after the electrodialytic experiments is also shown in Fig. 5. Anionic or uncharged species present in the suspensions will not be removed from the suspension in the two-compartment cell and are thus not considered removed. The percentages of metals in the liquid of the material suspension are shown in Fig. 6. It was observed that anionic/uncharged metal species up to $40 \%$ remained in the two-compartment cell, this was particularly the case for chloride rich materials such as harbour sediments and ashes. Based on this, the overall removal was highest for most materials when using the three-compartment cell. Contrarily, the combined dissolved (Fig. 6) and removed (Fig. 5) metal amounts from the materials were higher in the two-compartment cell for the KMC soil (S2), fly ash and lake sediment compared to the three-compartment cell. For the other materials the combined dissolved and removed percentages were higher when using the threecompartment cell, even if the $\mathrm{pH}$ was lower in the experiments with the two-compartment cells.

The percentage of the total charge passed by the metal ions (Pmetal) was calculated assuming that the metals are removed as the respective metal cation (As not included) and are shown in Table 3 .

$\mathrm{P}_{\text {metal }}=\mathrm{Q}_{\text {metal }} / \mathrm{Q}_{\text {total }} \times 100 \%$,

Where $\mathrm{Q}_{\text {metal }}(\mathrm{mol})=$ metal removed $\times$ ion valence and $\mathrm{Q}_{\mathrm{tot}}(\mathrm{mol})=(\mathrm{I} \times \mathrm{t}) /$ Faradays number

Naturally, the percentages follow the metal removal in Fig. 5, but the lower current density for the materials with low electrical conductivity (soil, mine tailing and lake sediment) had a lower total charge transfer. Up to $9 \%$ of the current was used to transport the analyzed metal ions in the experiments with the Collstrop soil (S1), which was the highest percent of current carried by those metals of all materials, followed by $5 \%$ and 3.5\% for Avedøre sewage sludge ash (SSA 1) and Zinkgruvan mine tailing (MT2). For all the other experiments, less than $1.5 \%$ of the current was used to remove the metal ions. The main ion carrying the current in all experiments was probably $\mathrm{H}^{+}$; both produced directly at the anode in the material suspension in the twocompartment cells and from the water splitting at the anion exchange membrane in the threecompartment cells. As the materials are acidified, also major ions such as $\mathrm{Ca}^{2+}, \mathrm{Mg}^{2+}, \mathrm{K}^{+}, \mathrm{Fe}^{2+}$ and $\mathrm{Al}^{3+}$ are expected to be available for electromigration (removal data for $\mathrm{Mg}, \mathrm{K}, \mathrm{Fe}$ and $\mathrm{Al}$ not shown). Generally, the percentages of the major ions carried by the current were $\mathrm{Ca}^{2+}>\mathrm{Al}^{3+}$, $\mathrm{Mg}^{2+}>\mathrm{Fe}^{2+}, \mathrm{K}^{+}$regardless of the material. $\mathrm{Ca}^{2+}$ is a dominant major ion in the materials and is present in the form of different minerals, mainly $\mathrm{CaCO}_{3}$, but also as $\mathrm{CaOH}$ or $\mathrm{CaSO}_{4}$ in fly ashes. $\mathrm{Ca}$ is released at higher $\mathrm{pH}$ than the heavy metals which are mainly released at $\mathrm{pH} 2-3$ and $\mathrm{Ca}$ is also present in higher concentrations than the heavy metals. Thus, a high amount of $\mathrm{Ca}$ is released into the suspension and is available for electromigration. However, for the KMC soil (S2), fly ash, Zinkgruvan mine tailing (MT 2) and lake sediment over $100 \%$ of the current could be calculated to be passed by $\mathrm{Ca}^{2+}$. This is naturally a contradiction and indicates other $\mathrm{Ca}^{2+}$ removal paths than electromigration. A hypothesis could be that at high $\mathrm{Ca}^{2+}$ concentrations in the material suspensions and high electrical conductivities in the catholyte an ion exchange over the cation exchange membrane of $\mathrm{Ca}^{2+}$ from the suspension and $\mathrm{H}^{+}$in the catholyte 1 . To keep the electroneutrality in the system, this exchange has to take place and the additional amounts of $\mathrm{Ca}^{2+}$ will be measured in the catholyte. The percentage of $\mathrm{Mg}^{2+}, \mathrm{K}^{+}$and $\mathrm{Fe}^{2+}$ and $\mathrm{Al}^{3+}$ ions carried by the current was $9-70 \%$ depending on the experiments, see Table 3 . Comparing the 
stirred system to a stationary set-up from the Collstrop soil (same site as S1), where a $52 \%$ removal was seen, only $2.5 \%$ of the current was carried by the $\mathrm{Cu}^{2+}$ ion in the stationary cell [18] compared to 7-9.3\% in the experiments with the stirred systems in this study. This could imply that in the stirred system as discussed above, a significant amount of metals are removed simply by ion exchange over the cation exchange membrane, and this should be studied further. In the fly ash and harbour sediments, $\mathrm{Cl}^{-}$is also considered to be an important current carrier. However, it is difficult to quantify the percentage of the current transported by $\mathrm{Cl}^{-}$as $\mathrm{Cl}^{-}$reaching the anode will react and evaporate as $\mathrm{Cl}_{2}(\mathrm{~g})$.

\subsection{The influence of material characteristics on the electrodialytic remediation}

VIP plots for the PLS model are shown in Fig. 7. In the experimental space studied the cell design was not varied with the other variables (material, current density), and therefore the experiments in the two-compartment cell mirrored the settings for the three-compartment cell experiments. For this reason, PLS models were calculated separately for each cell design, and this also highlights differences in variable importance for the two cell designs. Due to the difference in variable importance for the metals (as seen in Fig. 2), PLS models for each metal were calculated. The models were good and stable (R2Y 0.52-0.97; Q2 0.3-0.9) and the VIP values revealed differences in the influence of material characteristic for the removal of the different metals. High VIP values $(>1)$ represent a high influence of the variable in the model, and VIP values $<0.5$ indicate a low influence of the variable on the model. For a better overview of the influence of metal composition on the removal of metals, for the removal of As, $\mathrm{Cd}, \mathrm{Cr}, \mathrm{Cu}, \mathrm{Pb}$ and $\mathrm{Zn}$ (Fig. $7 \mathrm{c}-\mathrm{g}$ ) only metals that have a high influence (VIP>1) in at least one of the cell designs was included in Fig. 7.

For the material remaining after the electrodialytic treatment, the VIP-values were generally similar in the two cell set-ups (Fig. 7a). The initial concentration of $\mathrm{Ca}$, the initial $\mathrm{pH}$ of the material and the current density had the highest influence on the dissolution of material during the electrodialytic remediation experiments. This is likely related to the dissolution of carbonates in the initial phase of electrodialytic remediation resulting in a higher dissolution of materials with high $\mathrm{pH}$ and content of $\mathrm{Ca}$. For the removal of $\mathrm{Ca}$ the importance of material characteristics was similar for the two cell set-ups (Fig. 7b), where the initial $\mathrm{pH}$ and initial concentrations of $\mathrm{Cd}$ and $\mathrm{Zn}$ had the highest influence on the removal. This means that a low $\mathrm{pH}$ in the experimental material resulted in higher removal of $\mathrm{Ca}$, which is related to a higher mobilisation of $\mathrm{Ca}$ at lower $\mathrm{pH}$. The calculations also showed that high concentrations of $\mathrm{Cd}$ and $\mathrm{Zn}$ would inhibit the removal of $\mathrm{Ca}$, suggesting that $\mathrm{Cd}$ and $\mathrm{Zn}$ are mobilised at higher $\mathrm{pH}$ than the remaining metals, thus competing with $\mathrm{Ca}$ for the current.

For the removal of all metals (Fig. $7 \mathrm{c}-\mathrm{h}$ ), current density had low influence in comparison with the material in general. This is in line with previous studies of soil [13] and harbour sediment [14], in which it was found that soil/sediment characteristics were more important than current density for the efficiency of electrodialytic remediation.

The removal of As and $\mathrm{Cr}$ (Fig. $7 \mathrm{c}-\mathrm{d}$ ) had the highest deviation in the variable importance between the two cell set-ups. The deviation in variable importance for As could be related to the formation of both positively and negatively charged ions, resulting in a difference in the transport out of the main compartment of the electrodialytic cell in the two set-ups. This means that if As is the target metal to remediate, the 3-compartment cell would be the better choice. The 
deviation in variable importance for $\mathrm{Cr}$ is likely related to the low removal efficiencies, with limited difference in removal efficiencies between the two cell setups.

The removal of $\mathrm{Cd}, \mathrm{Cu}, \mathrm{Pb}$ and $\mathrm{Zn}$ had similar variable importance in the two cell set-ups (Fig. 7 $\mathrm{e}-\mathrm{h}$ ). The initial concentration of $\mathrm{Ca}$ and $\mathrm{pH}$ had a high influence on the removal of these metals and are as mentioned earlier related to the buffer capacity of the materials. $\mathrm{Ca}$ is likely related to carbonates in the materials, known to highly influence the acidification rate in the initial phase of electrodialytic remediation. Furthermore, if the target metals of remediation are $\mathrm{Cd}, \mathrm{Cu}, \mathrm{Pb}$ and $\mathrm{Zn}$ in chloride-rich materials, the three-compartment cell would be better, as these metals also form negatively charged chloride complexes. The influence of metal bonding in the materials is also of high importance to the removal and various metals influence the removal of different metals. This can be seen in Fig. 7f, where the initial concentration of $\mathrm{Cd}, \mathrm{Pb}$ and $\mathrm{Zn}$ influences $\mathrm{Cu}$ removal, whereas $\mathrm{Cu}$ mostly influences the $\mathrm{Pb}$ removal (Fig. $7 \mathrm{~g}$ ). This could be related to how the metals are bound in the different materials and how they are mobilised during the electrodialytic remediation.

\section{Conclusions}

This study showed that the removal efficiency between the two electrodialytic remediation cells is dependent on the material that is subjected to treatment. Slightly higher removal efficiencies were generally seen for the three-compartment cell experiments, except for one soil.

Acidification in the two-compartment cell was faster than in the three-compartment cell, and the released percentages of metals were higher in the two-compartment cell for some materials. Operationally, the two-compartment cell works with a lower voltage drop and thus lower energy consumption than the three-compartment cell. Accordingly, for industrial use, the twocompartment cell is a better choice, but only for materials where the metals are released and present as cations. The amount of current carried by the heavy metal ions was similar between the two set-ups, even with the lower $\mathrm{pH}$ and higher electrical conductivity in the twocompartment cell. The major ions, especially $\mathrm{Ca}^{2+}$, and protons are the main current carrier. The multivariate models revealed that the $\mathrm{pH}, \mathrm{Ca}$ and metal bonding are of high importance for the design of remediation, whereas the current density has low importance. The choice of cell set-up and experimental settings depends on the metal(s) targeted for remediation, the remediation objectives and material to be remediated. Thus, the multivariate analysis can be a valuable tool for designing electrodialytic remediation experiments in future studies.

\section{Acknowledgements}

Laboratory technicians Ebba Schnell, Sabrina Hviid and Malene Grønvold are thanked for analytical analysis and performing the electrodialytic experiments. The work was funded by Copenhagen Cleantech Cluster (CCC) as a GAP project. 


\section{References}

[1] L. M. Ottosen , I. V. Kristensen, A. J. Pedersen , H. K. Hansen, A. Villumsen, A. B. Ribeiro, Electrodialytic Removal of Heavy Metals from Different Solid Waste Products, Sep. Sci. Technol., 38:6 (2003) 1269-1289.

[2] L.M. Ottosen, P.E. Jensen, G.M. Kirkelund, C. Dias-Ferreira, H.K. Hansen, Electrodialytic remediation of heavy metal polluted soil - treatment of water saturated or suspended soil. Chem. Eng.Trans. 26 (2012) 103-108.

[3] G.M. Nystroem, L.M. Ottosen, A. Villumsen, Test of experimental set-ups for electrodialytic removal of $\mathrm{Cu}, \mathrm{Zn}$, $\mathrm{Pb}$ and $\mathrm{Cd}$ from different contaminated harbour sediments, Eng. Geology 77 (3-4) (2004) 349-357..

[4] A. Rojo, H. K. Hansen, Electrodialytic Remediation of Copper Mine Tailings: Sulphuric and Citric Acid Addition, Sep. Sci. Technol., 40:9 (2005) 1947-1956.

[5] C. Dias-Ferreira, G.M. Kirkelund, L.M. Ottosen, Ammonium citrate as enhancement for electrodialytic soil remediation and investigation of soil solution during the process. Chemosphere 119 (2015) 889-895.

[6] A. J. Pedersen, Evaluation of assisting agents for electrodialytic removal of $\mathrm{Cd}, \mathrm{Pb}, \mathrm{Zn}, \mathrm{Cu}$ and $\mathrm{Cr}$ from MSWI fly ash, J. Haz. Mat. B95 (2002) 185-198.

[7] L.M. Ottosen, P.E. Jensen, G.M. Kirkelund, B.E. Ebbers, Electrodialytic separation of heavy metals from particulate material,WO2015032903-A1 (2015).

[8] B. Ebbers, L.M. Ottosen, P.E. Jensen, Comparison of two different cells for separation of phosphorus and heavy metals from sewage slugde ash. Chemosphere 125 (2015) 122-129.

[9] L.M. Ottosen, H.K. Hansen, C. Hansen, Water splitting at ionexchange membranes and potential differences in soil during electrodialytic soil remediation, J. Appl. Electrochem., 30 (2000) 1199-1207

[10] L.M. Ottosen, P.E. Jensen, G.M. Kirkelund, Phosphorous recovery from sewage sludge ash suspended in water in a two-compartment electrodialytic cell, Waste Manage. 51 (2016) 142-148.

[11] K.B. Pedersen, L.M. Ottosen, P.E. Jensen, T. Lejon. Comparison of 2-compartment, 3-compartment and stack designs for electrodialytic removal of heavy metals from harbour sediments, Electrochim. Acta, 181 (2015) 48-57.

[12] G.M. Kirkelund, C. Magro, P. Guedes, P.E. Jensen, A.B. Ribeiro, L.M. Ottosen, Electrodialytic removal of heavy metals and chloride from municipal solid waste incineration fly ash and air pollution control residue in suspension - test of a new two compartment experimental cell, Electrochim. Acta, 181 (2015) 73-81.

[13] K.B. Pedersen, P.E. Jensen, L.M. Ottosen, J. Barlindhaug, The relative influence of electrokinetic remediation design on the removal of $\mathrm{As}, \mathrm{Cu}, \mathrm{Pb}$ and $\mathrm{Sb}$ from shooting range soils. Eng.Geol. 238 (2018) 52-61.

[14] K.B. Pedersen, T. Lejon, P.E. Jensen, L.M. Ottosen, The influence of sediment properties and experimental variables on the efficiency of electrodialytic removal of metals from sediment, J.Environ.Chem. Eng. 5 (2017) 53125321.

[15] K.B. Pedersen, G.M. Kirkelund, L.M. Ottosen, P.E. Jensen, T. Lejon, Multivariate methods for evaluating the efficiency of electrodialytic removal of heavy metals from polluted harbour sediments, J. Hazard. Mater. 283 (2015) 712-720.

[16] DS259, Determination of metals in water, sludge and sediments - General guidelines for determination by atomic absorption spectrophotometry in flame (2003)

[17] Carlson, R., Carlson, J.E., 2005c. Chapter 18 quantitative relations: observed responses and experimental variations. In: Rolf, C., Johan, E.C. (Eds.), Data Handling in Science and Technology. Elsevier, pp. 425-469.

[18] L. M. Ottosen, H. K. Hansen, G. Bech-Nielsen, A. Villumsen, Electrodialytic Remediation of an Arsenic and Copper Polluted Soil - Continuous Addition of Ammonia During the Process, Environ. Technol. 21:12 (2000)

$1421-1428$. 
a)

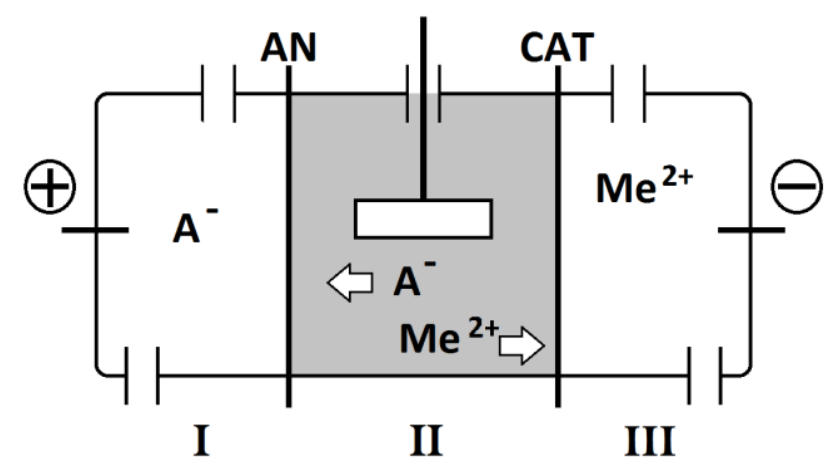

b)

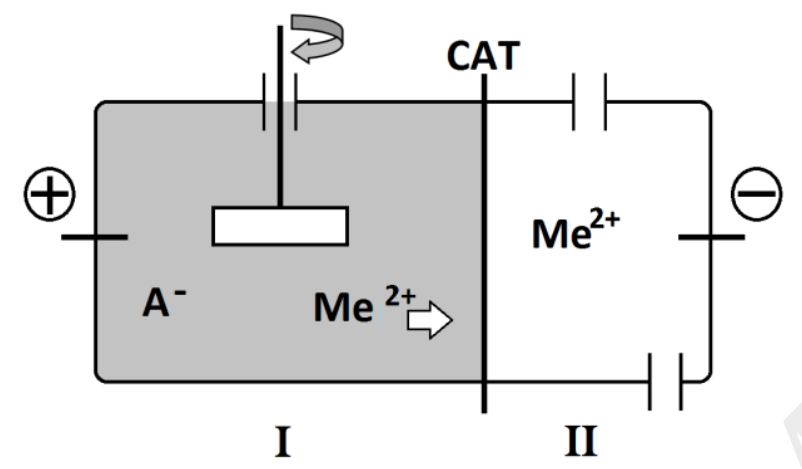

Fig. 1. The experimental set-up of the a) three- and b) two-compartment electrodialytic cell. ANanion exchange membrane, CAT-cation exchange membrane, A - anion, Me - metal. 
a)

PCA scores plot

- Low conductivity

- High conductivity

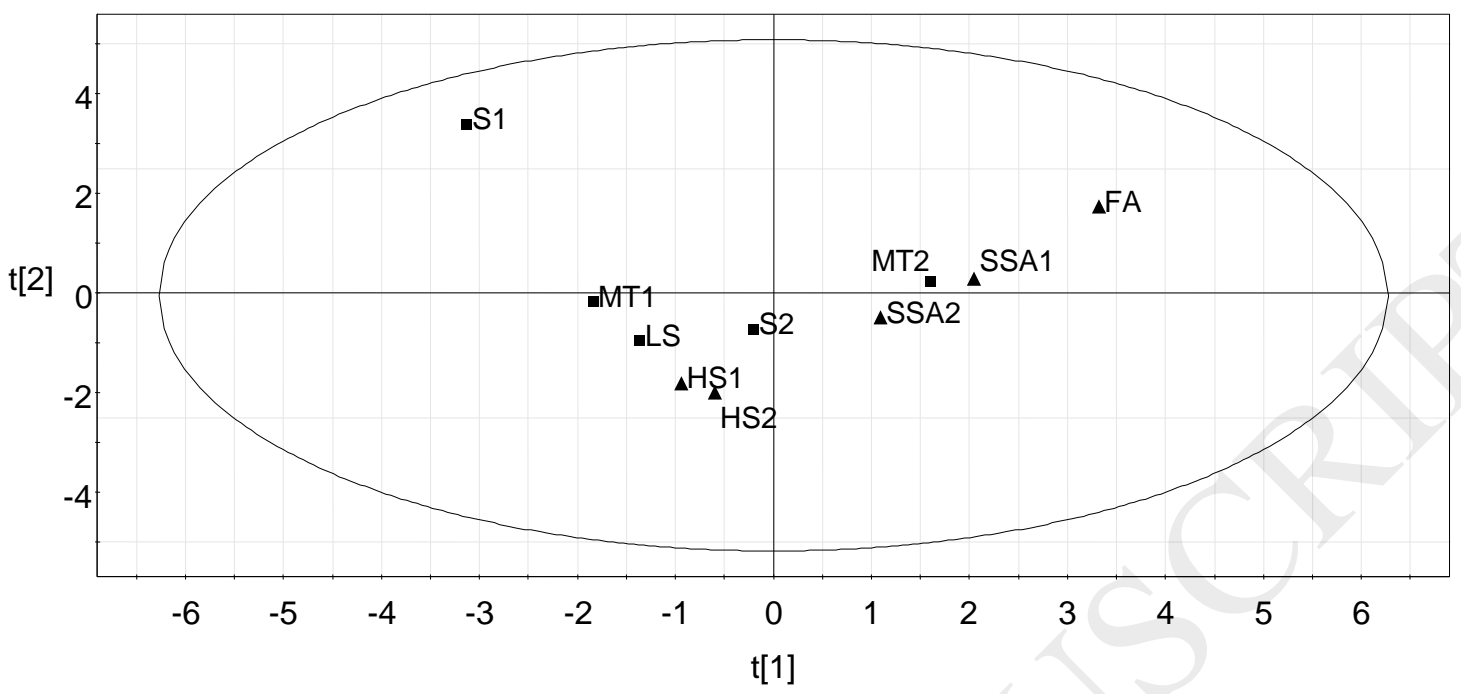

b)

PCA loadings plot

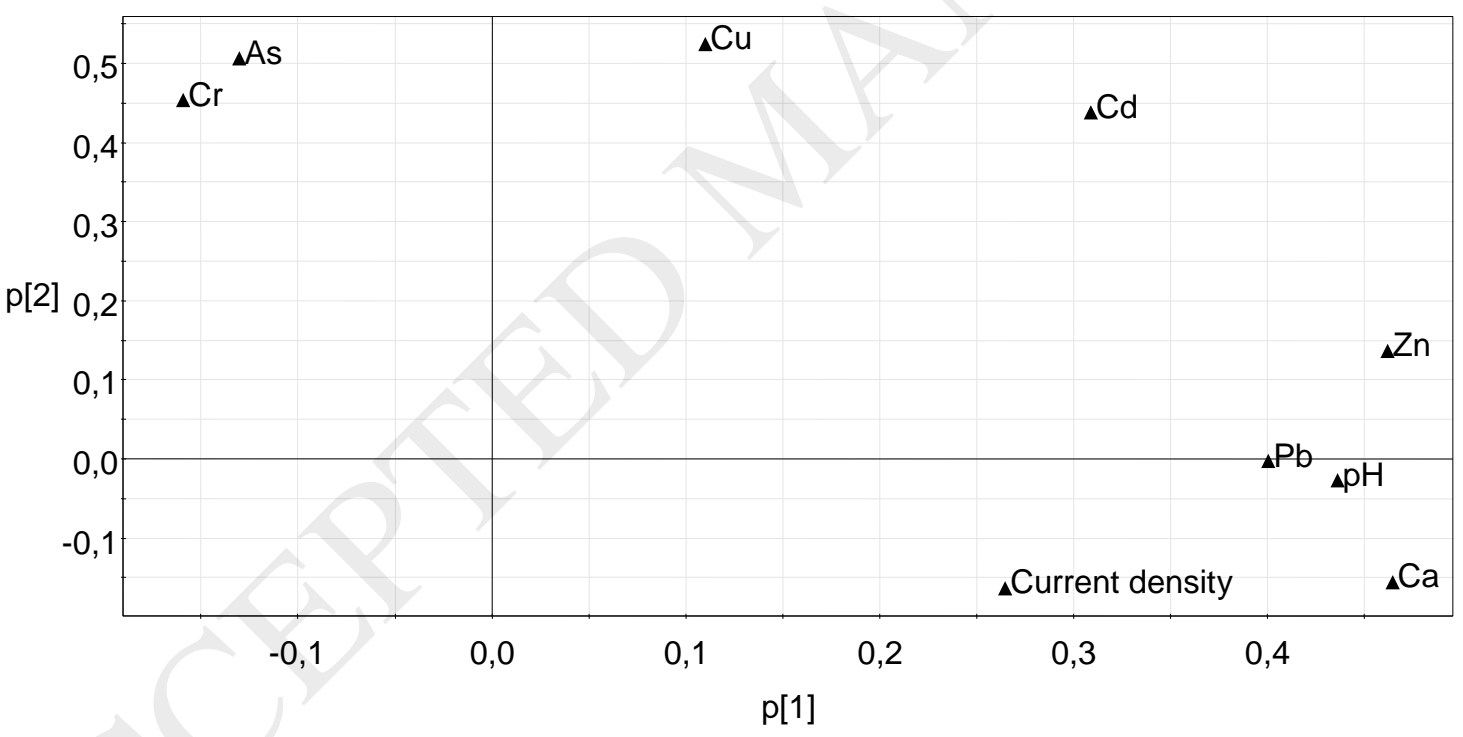

Fig. 2 PCA model explaining $78 \%$ (first component 47\%, second component $31 \%$ ) of the variance of metals, $\mathrm{pH}$ and current density in the studied materials. a). Scores plot, materials of low/high conductivity are distinguished in the figure (box/triangle). b). Loadings plot. 


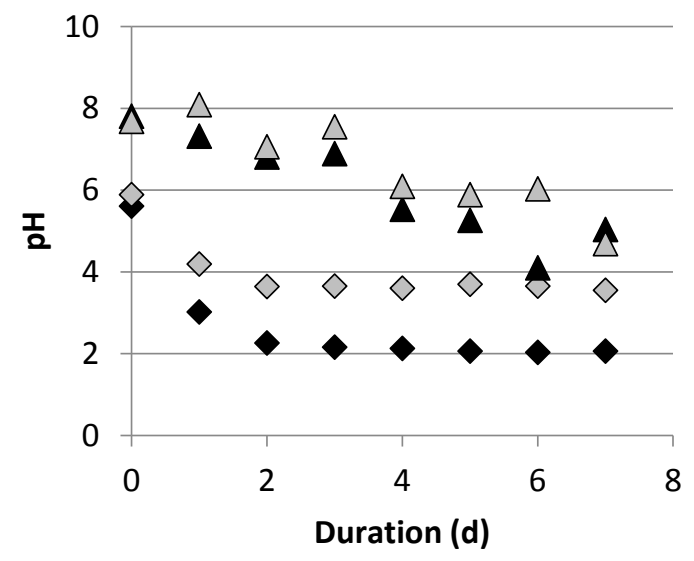

$\diamond \mathrm{S} 1-2 \mathrm{C} \diamond \mathrm{S} 1-3 \mathrm{C} \quad \Delta \mathrm{S} 2-2 \mathrm{C} \quad \Delta \mathrm{S} 2-3 \mathrm{C}$

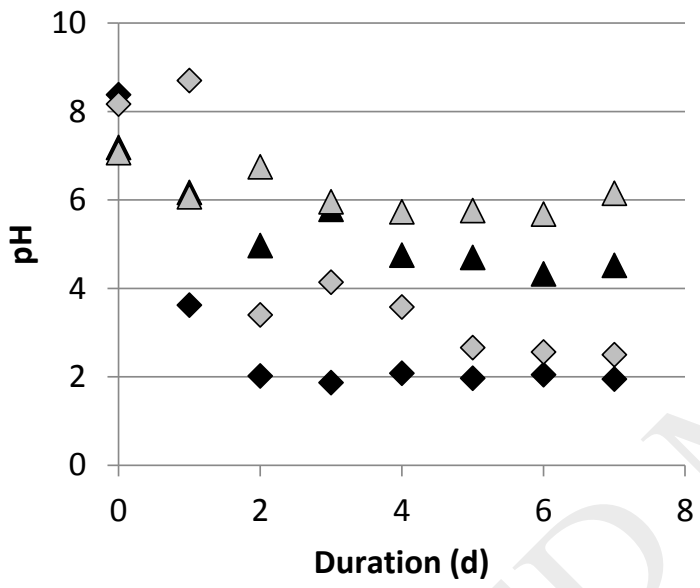

- MT 1-2C $\diamond \mathrm{MT} 1-3 \mathrm{C} \quad \triangle \mathrm{MT} 2-2 \mathrm{C} \quad \triangle \mathrm{MT} 2-3 \mathrm{C}$

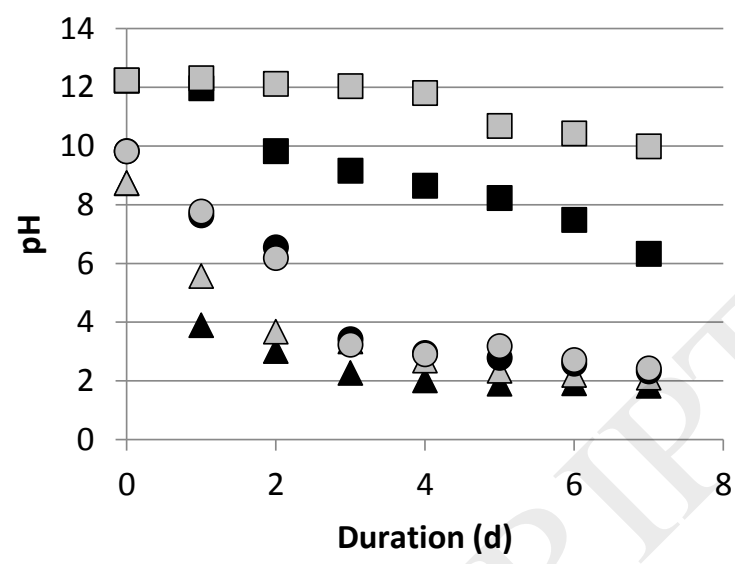

- FA-2C $\square F A-3 C \triangle S S A 1-2 C \triangle S S A 1-3 C \bullet S S A$ 2-2C OSSA-2 3C

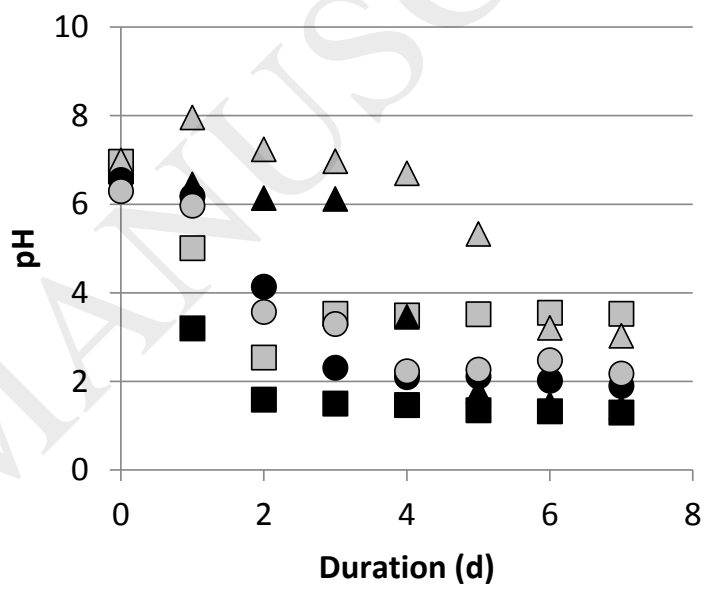

-HS 1-2C $\square$ HS 1-3C $\Delta$ HS 2-2C $\Delta$ HS 2-3C $\bullet$ LS-2C O LS-3C

Fig. 3. pH development in the material suspensions during the experiments, a) soil, b) ash, c) mine tailing, d) sediment 

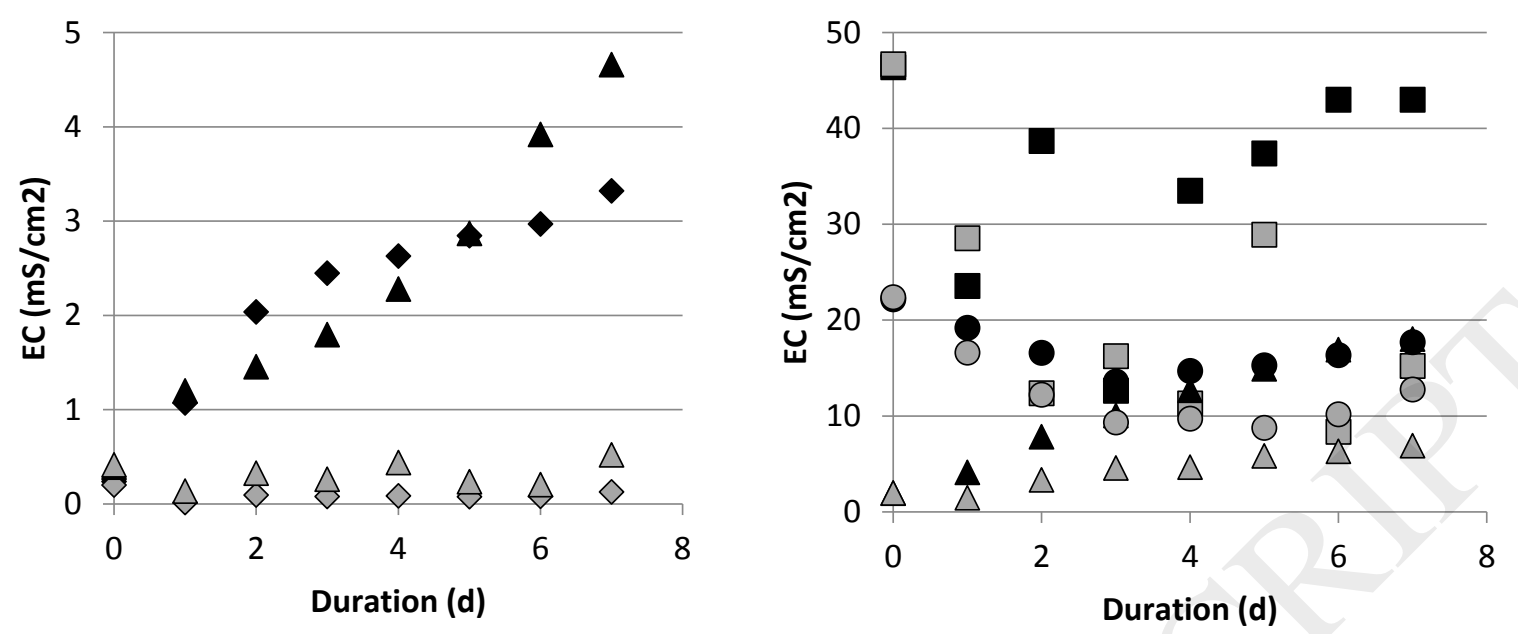

$\bullet \mathrm{S} 1-2 \mathrm{C} \diamond \mathrm{S} 1-3 \mathrm{C} \Delta \mathrm{S} 2-2 \mathrm{C} \Delta \mathrm{S} 2-3 \mathrm{C}$

- FA-2C $\square$ FA-3C $\triangle$ SSA 1-2C $\triangle$ SSA 1-3C • SSA 2-2C O SSA-2 3C
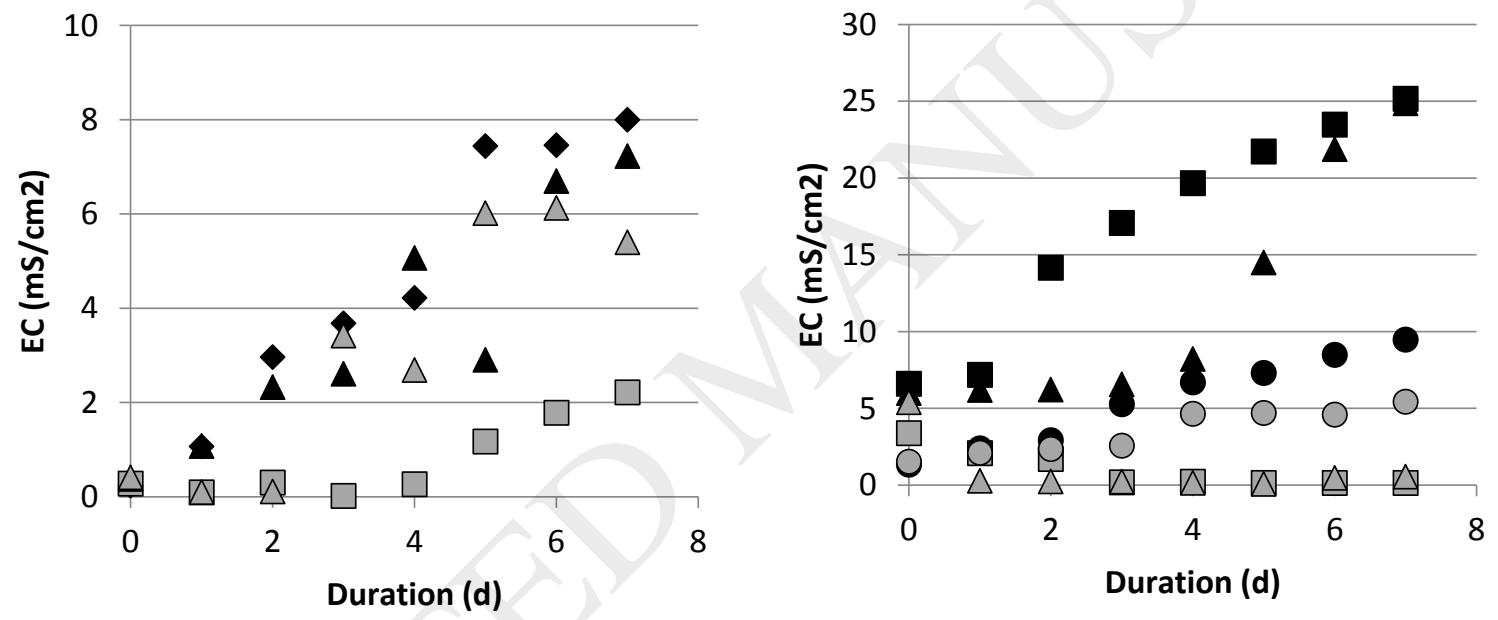

• MT 1-2C $\square$ MT 1-3C $\triangle$ MT 2-2C $\triangle$ MT 2-3C

$\square$ HS 1-2C $\square$ HS 1-3C $\Delta$ HS 2-2C $\triangle$ HS 2-3C - LS-2C O LS-3C

Fig. 4. Electrical conductivity development in the material suspensions during the experiments, a) soil, b) ash, c) mine tailing, d) sediment 


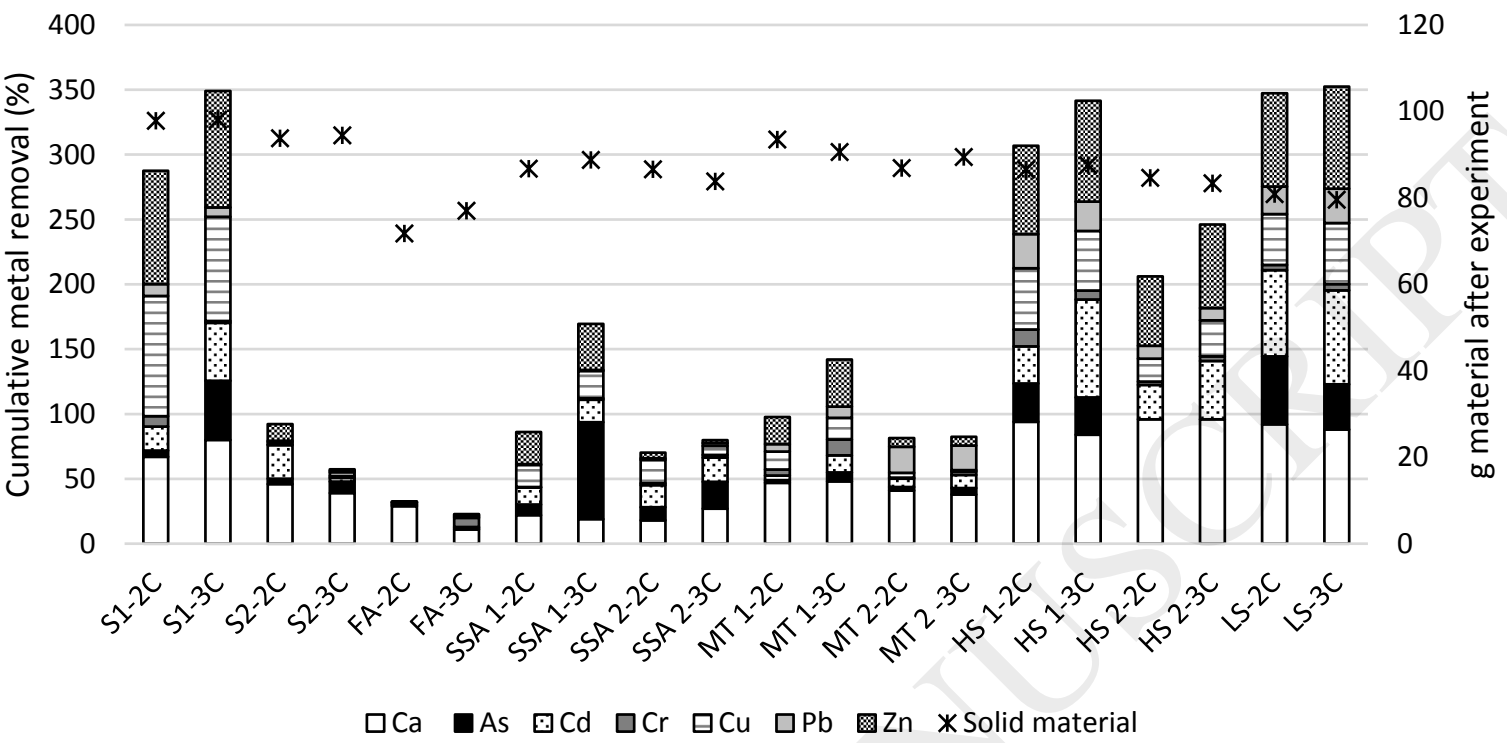

Fig. 5. Cumulative metal removal in the electrodialytic experiments and amount of remaining material after electrodialytic experiments 


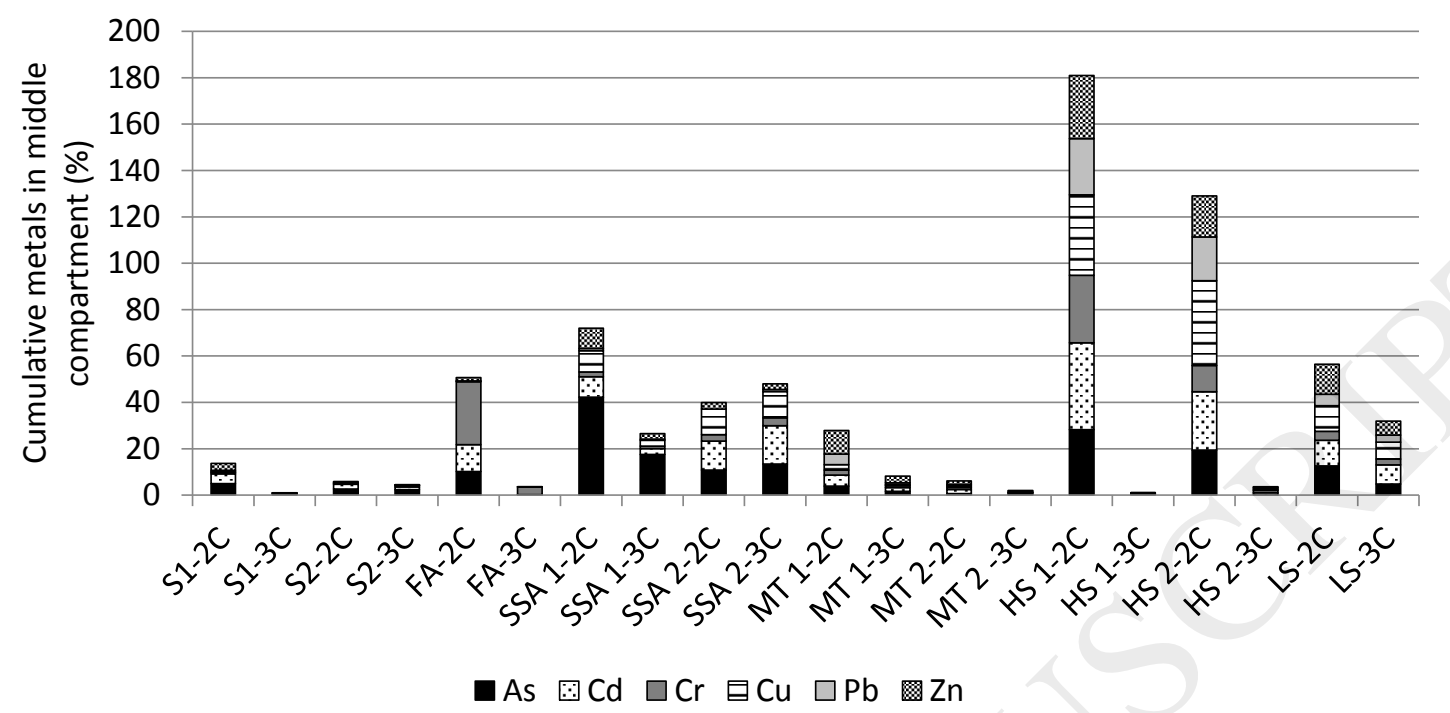

Fig. 6. Percentage of metals found in the liquid of the suspension after the electrodialytic experiments 
a)

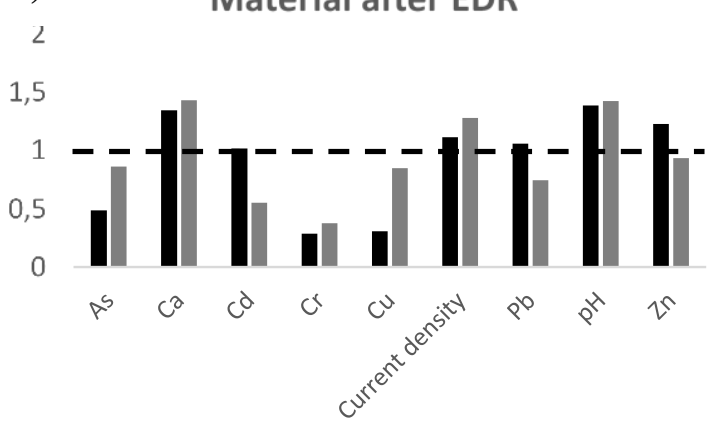

c)

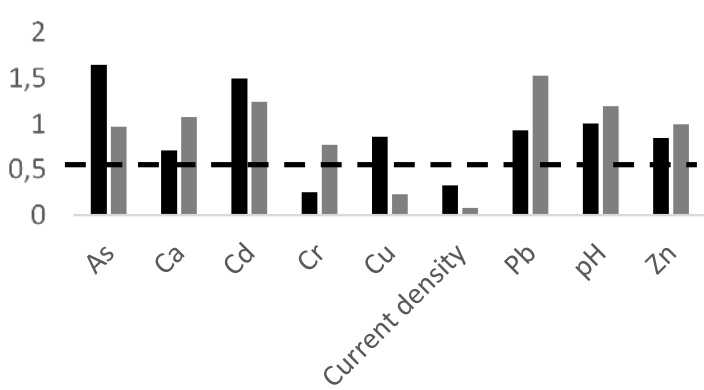

e)

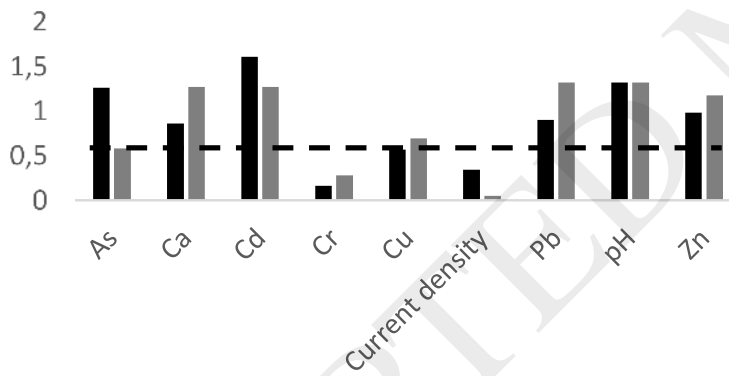

g)

$\mathrm{Pb}$

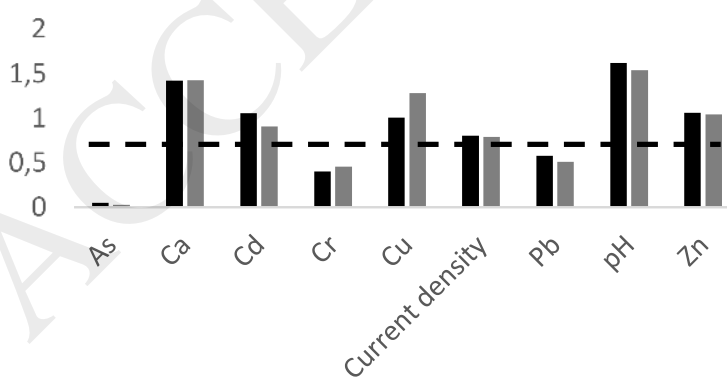

b)

$\mathrm{Ca}$

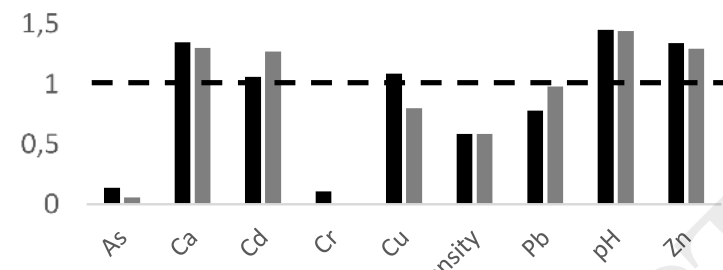

d)

$\mathrm{Cr}$

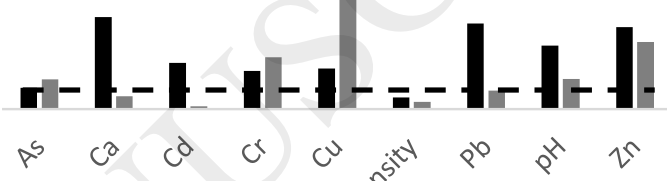

f)

$\mathrm{Cu}$

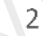

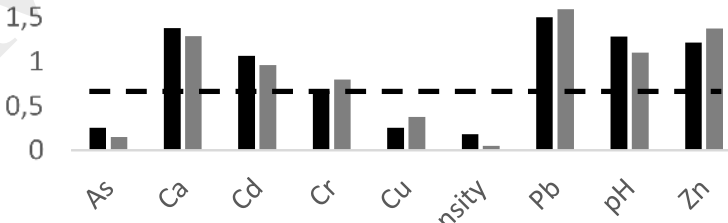

h)

Zn

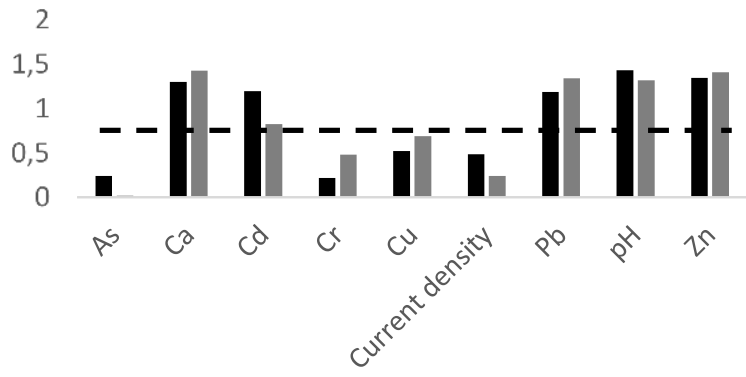


Fig. 7: Variable importance in the projection (VIP) values for the PLS models of material removed after ed and metal removal efficiencies, in the two- and three-compartment cell design. The VIP values (unitless) were calculated for each variable (x-axis) by summing the squares of the PLS loading weights. 
Table 1. Experimental waste materials

\begin{tabular}{|c|c|c|c|}
\hline Waste materials & Sample name & Origin & Description \\
\hline Soil & $\mathrm{S} 1$ & Collstrop, Denmark & $\begin{array}{l}\text { CCA-contaminated } \\
\text { site }\end{array}$ \\
\hline Soil & $\mathrm{S} 2$ & $\begin{array}{l}\text { Kalvebod } \\
\text { Miljøcenter (KMC) } \\
\text { 2, Denmark }\end{array}$ & $\begin{array}{l}\text { Origin unknown, } \\
\text { sampled from soil } \\
\text { treatment facility }\end{array}$ \\
\hline Fly ash & FA & Sisimiut, Greenland & $\begin{array}{l}\text { Small scale grate } \\
\text { fired MSWI facility }\end{array}$ \\
\hline Sewage sludge ash & SSA1 & Avedøre, Denmark & $\begin{array}{l}\text { From fluidized bed } \\
\text { incineration. } \mathrm{P} \\
\text { precipitation with } \mathrm{Fe} \text {. }\end{array}$ \\
\hline Sewage slugde ash & SSA2 & Lundtofte, Denmark & $\begin{array}{l}\text { From fluidized bed } \\
\text { incineration. } \mathrm{P} \\
\text { precipitation with } \mathrm{Al} \text {. }\end{array}$ \\
\hline Mine tailing & MT1 & Nalunaq, Greenland & Au mine \\
\hline Mine tailing & MT2 & Zinkgruvan, Sweden & $\mathrm{Zn}, \mathrm{Cu}$ and $\mathrm{Pb}$ mine. \\
\hline Harbour sediment & HS1 & Hammerfest, Norway & Industrial harbour \\
\hline Harbour sediment & HS2 & Sisimiut, Greenland & Industrial harbour \\
\hline Lake sediment & LS & $\begin{array}{l}\text { Stampedam, } \\
\text { Denmark }\end{array}$ & $\begin{array}{l}\text { Former metalindustry } \\
\text { outlet }\end{array}$ \\
\hline
\end{tabular}


Table 2. Characteristics of the experimental materials (n.d.- not detected)

\begin{tabular}{lcccccccc}
\hline & $\mathrm{pH}$ & $\begin{array}{l}\mathrm{As} \\
(\mathrm{mg} / \mathrm{kg})\end{array}$ & $\mathrm{Ca}(\mathrm{g} / \mathrm{kg})$ & $\begin{array}{l}\mathrm{Cd} \\
(\mathrm{mg} / \mathrm{kg})\end{array}$ & $\begin{array}{l}\mathrm{Cr} \\
(\mathrm{mg} / \mathrm{kg})\end{array}$ & $\begin{array}{l}\mathrm{Cu} \\
(\mathrm{mg} / \mathrm{kg})\end{array}$ & $\begin{array}{l}\mathrm{Pb}(\mathrm{mg} \\
/ \mathrm{kg})\end{array}$ & $\begin{array}{l}\mathrm{Zn} \\
(\mathrm{mg} / \mathrm{kg})\end{array}$ \\
\hline \hline S1 & 5.8 & 355 & 1.24 & 6.6 & 789 & 1746 & 23.4 & 131 \\
S2 & 7.7 & 6.9 & 52.3 & 0.9 & 10.8 & 365 & 392 & 405 \\
FA & 12.5 & 63 & 237 & 113 & 71.1 & 565 & 1082 & 9701 \\
SSA 1 & 10.3 & 3.1 & 168 & 14.3 & 46.4 & 672 & 283 & 2536 \\
SSA 2 & 10.0 & 2.5 & 104 & 1.6 & 51.1 & 458 & 110 & 2064 \\
MT 1 & 8.2 & 111 & 14.7 & 2.6 & 25.4 & 98.8 & 54.6 & 31.0 \\
MT 2 & 7.7 & 21.3 & 54.1 & 11.7 & 5.1 & 372 & 3710 & 7346 \\
HS 1 & 7.7 & 2.0 & 9.73 & 0.9 & 16.0 & 96.6 & 67.8 & 207 \\
HS 2 & 8.2 & n.d. & 42.1 & 0.6 & 25.0 & 81.2 & 103 & 173 \\
LS & 6.6 & 2.4 & 17.3 & 1.5 & 31.3 & 140 & 138 & 186
\end{tabular}


Table 3: Percentage of the current carried by specified ions, metal $\left(\mathrm{Cd}^{2+}, \mathrm{Cr}^{3+}, \mathrm{Cu}^{2+}, \mathrm{Pb}^{2+}, \mathrm{Zn}^{2+}\right)$, major ions $\left(\mathrm{Al}^{3+}, \mathrm{Ca}^{2+}, \mathrm{Fe}^{2+}, \mathrm{K}^{+}, \mathrm{Mg}^{2+}\right)$

\begin{tabular}{lccc|ccc}
\hline & \multicolumn{3}{|c}{ Two-compartment cell } & \multicolumn{3}{c}{ Three-compartment cell } \\
\hline \hline & $\left.\mathrm{P}_{\text {metal }} \%\right)$ & $\mathrm{P}_{\text {major ions }}(\%)$ & $\mathrm{P}_{\mathrm{Ca}}{ }^{2+}(\%)$ & $\left.\mathrm{P}_{\text {metal }} \%\right)$ & $\mathrm{P}_{\text {major ions }}(\%)$ & $\mathrm{P}_{\mathrm{Ca}}{ }^{2+}(\%)$ \\
S 2 & 9.3 & 38 & 9 & 7.0 & 24 & 9 \\
FA & 0.3 & 183 & 180 & 0.1 & 133 & 129 \\
SSA 1 & 0.2 & 134 & 107 & 0.4 & 63 & 38 \\
SSA 2 & 3.4 & 120 & 61 & 5.1 & 90 & 52 \\
MT 1 & 0.8 & 60 & 30 & 0.3 & 66 & 41 \\
MT 2 & 3.1 & 76 & 57 & 0.2 & 71 & 58 \\
HS 1 & 1.3 & 205 & 175 & 3.5 & 181 & 166 \\
HS 2 & 0.5 & 74 & 23 & 2.0 & 29 & 22 \\
LS & 1.2 & 144 & 63 & 0.7 & 75 & 68 \\
& & & 130 & 1.2 & 142 & 130
\end{tabular}

